\title{
Relation Between R\&D Expenditures And Economic Growth: Empirical Evidence From BRICS-T Countries
}

\author{
Ar-Ge Harcamaları ile Ekonomik Büyüme Arasındaki İlişki: BRICS-T Ülkelerinden Ampirik Kanıtlar
}

\author{
Yavuz Özek ${ }^{1 *}$
}

${ }^{1}$ Department of Banking and Insurance, Firat University, Elazig, Turkey

\begin{tabular}{lllll}
\hline Received: 28.06 .2020 & Accepted: 17.08 .2020 & This article was checked by intihal.net & ISSN: 2149-8598 \\
\hline
\end{tabular}

\begin{abstract}
The transformation process in the economic structure of world has made it obligatory for the countries to follow the developments in the fields of information, innovation and technology in order to achieve economic growth, increase efficiency and competitiveness. This is possible with the investments and expenditures made for research and development activities, which forms the basis of endogenous growth models.

In this study, the effects of research and development expenditures on economic growth in BRICS-T are analyzed by employing annual data belonging to $2003-2017$ period. Results obtained from panel data methods imply that research and development expenditure is effective on economic growth in only long run. On the other hand, when economy grows, research and development expenditures increase in the short run. In country specific analysis, bi-directional causation linkage is found only in the Turkish economy.
\end{abstract}

Keywords: R\&D, Growth, Panel Data

$\ddot{O} z$

Dünyanın ekonomik yapısındaki dönüşüm süreci, ülkelerin ekonomik büyümeyi sağlamak, verimliliği ve rekabet gücünü artırmak için bilgi, yenilik ve teknoloji alanlarındaki gelişmeleri takip etmesini zorunlu kılmıştır. Bu, içsel büyüme modellerinin temelini oluşturan araştırma ve geliştirme faaliyetlerine yapılan yatırım ve harcamalarla mümkündür.

Bu çalışmada, 2003 - 2017 dönemine ait yıllık veriler kullanılarak BRICS-T’ de araştırma ve geliştrirme harcamalarının ekonomik büyüme üzerindeki etkileri analiz edilmiştir. Panel veri yöntemlerinden elde edilen sonuçlar, araşıırma ve geliştirme harcamalarının sadece uzun vadede ekonomik büyüme üzerinde etkili olduğunu göstermektedir. Öte yandan, ekonomi büyüdüğünde, kısa vadede araşıırma ve geliştirme harcamaları da artar. Ülkeye özel analizde, çift yönlü nedensellik bağlantısı sadece Türkiye ekonomisinde bulunmaktadır.

Anahtar Kelimeler: Ar-Ge, Büyüme, Panel Veri

Özek Y. (2020). "Relation Between R\&D Expenditures And Economic Growth: Empirical Evidence From BRICS-T Countries", Journal of Academic Value Studies, 6(3) 311-321 (http://dx.doi.org/10.29228/javs.44542).

\footnotetext{
*E-mail address: yozek@firat.edu.tr
} 


\section{Introduction}

Economic growth is defined as the real gross national product of the country or an increase in per capita income as a result of the continuous increase in productivity in a certain period of production. The causation linkage exists between economic growth, research and development $(\mathrm{R} \& \mathrm{D}$, hereafter) and innovation. Achieving economic growth is closely related to the development of factors listed above. When we observe experiences of developed countries, it is seen that they attach importance to technology-intensive production and export. In this respect, the causation linkage between R\&D, activities ending with innovation, export and growth becomes an important issue (Sungur et al., 2016: 186).

Neoclassical growth models that address technological developments externally, failed to explain the effect of technology on growth and endogenous growth models has become popular in 1980s. Endogenous growth models, which consider $\mathrm{R} \& \mathrm{D}$ as an engine of growth, have gained importance especially in the private sector and governmental institutions recently. Efficiency, innovation and contribution of $\mathrm{R} \& \mathrm{D}$ on growth of economy, which is proven by numerous studies in the literature, have effect on gaining importance of investment and expenditures for R\&D (Genç and Atasoy, 2010: 28).

The globalization process has made the developments in technology and innovation even more important by removing the economic boundaries and changing the competitive structure. The expenditures made for R\&D ensure the efficient use of resources with the knowledge and skills required for technology intensive production of the countries and companies and create a driving force on economic growth. An increase in $R \& D$ expenditures and investments contributes to the increase in this driving force and to sustain economic growth.

This study investigates how R\&D activities affect economic growth in Brazil, Russia, India, China, South Africa and Turkey (BRICS-T countries, hereafter). In the following section, theoretical background is created and literature is summarized. In the third section, methodology and tests are presented. Lastly, results of empirical tests are concluded and give a number of policy implications.

Textile and apparel industry makes major contributions to economies of developing countries. Textile-apparel is one of the leading sectors in Turkey and accounts for about 17\% of Turkish exports (Institute, 2018). Considering the significant share of textiles in Turkish economy which accounts for 16.3\% of industrial production and one-third of industrial employment, it is clear that studies involving this sector would directly contribute to sustainable development of the country (Tan et al., 2016).

Based on the current demographic trends, Turkish population, currently 81 million, is expected to reach 87 million by 2023 and 100 million by 2040 (Institute, 2018). These projections point to increasing demand for textiles in near future, which will necessitate use of more resources and result in higher amount of pollution discharge into the ecosystem (Shrivastava, 1995; Jakhar, 2015). Along with increasing population and consumption, use of resource and resources of pollution are also expected to rise (Özdoğan et al., 2007).

Environmental problems arise from increasing material and consumption-related material flows worldwide. According to $2011 \mathrm{FAO} / \mathrm{ICAC}$ survey of the United Nations, consumption of fiber and fiber-related end products (garment, home textile and industrial textiles) has increased 30-fold since 1950's(Tomovska et al., 2017) .

Textile and apparel industry is responsible for $10 \%$ of world's carbon emission (Muthukumarana et al., 2018). Thus, it is considered the second leading industrial polluter after petroleum industry (Conca, 2015). There are investigations to make activities of textile and apparel industry more eco-friendly to restore polluted environment and impaired natural balance (İşmal and Yıldırım, 2012). "Ecological Textile" concept aiming textile production in accordance with environmental and human health concerns has been introduced in 1990's to diminish the adverse effect of textile and apparel industry on environment (Oral et al., 2012).

EFTA practices could be defined as production of textile and apparel products using raw materials obtained from renewable resources, energy and other materials. In other words, EFTA products are manufactured using raw materials and energy from completely renewable resources (Muthu et al., 2012; Bruntland, 1987).

EFTA means materials produced in a manner considering the environmental considerations in all production stages from fiber to final product, a material which is not harmful to user and can be recycled after use (Bayraktar, 2005). Research 
areas related to EFTA products involve chemicals used in the processes throughout life of textile products from raw material to final product and its disposal, environment- and human health-related issues such as waste water, noise level and chimney gases (Oral et al., 2012).

Wastes of textile and apparel industry has been on increase along with the expanding production. It is important for textile industry that $97 \%$ of these wastes are recyclable. However, recycling of textile products as non-dangerous solid wastes are generally disregarded (Jordeva et al., 2015). In addition to technological processes applied to textile wastes, sorting and collecting them according to color and/or fiber content make it difficult to recycle the textile wastes (Larney and van Aardt, 2010).

Textile and apparel industry depends heavily on cotton production. Farmers willing to increase their cotton production tend to use higher amount of pesticides. For example, cotton farmers worldwide use more than $25 \%$ of world's total pesticide use of 2.6 billion dollars every year (Kang et al., 2013). Chemical fertilizers and pesticides decrease soil fertility and cause damage to environment and society. In addition, they can lead to serious environmental and health problems such as biodiversity loss, water pollution and poisoning (Kang et al., 2013). However, although pesticides are used in production of some natural fibers like cotton and wool, they are still environmentally friendly compared to petroleum-based fiber products (E. and S., 2011).

More than 50\% of wastes in textile industry result from late processes such as dyeing and finishing (Smith, 1994). Excess use of water, energy, dyeing materials and other chemicals in textile finishing leads to environmental pollution (İşsmal and Yıldırım, 2012).

Annual global production of textile and apparel industry is over 80 million tones, and improvements of environmental performance in this industry is quite important (Chen and Burns, 2006; Niinimäki, 2013). This necessitates a production considering product designing, marketing and after-use processes. Nevertheless, scientific eco-friendly production methods that could benefit businesses are still not sufficiently used. Consumers using textile and apparel products are not involved in sustainable designing processes (Thomas, 2008).

Since textile and apparel industry contributes to national economies and global wealth, it is clear that downsizing these industries will not be immediate solution of environmental problems (Kunz et al., 2007; Kang et al., 2013). Increasing the awareness of consumers towards the environmental problems has been suggested as a way for solving these problems (Kang et al., 2013; Fletcher, 2008).

Both policies and social attitudes towards EFTA products promote textile and apparel manufacturers for eco-friendly production activities. Some brands (Ecsquel, Saint Angelo, Levi's, Nike) made environmental problems a new competition advantage and started offering the consumers EFTA products (Liu et al., 2012).

In addition to social responsibilities, environmental awareness supported by legal regulations has been developing recently(Chi and Kilduff, 2011). Nevertheless, use of EFTA products are still limited (Kim and Damhorst, 1998; Tomovska et al., 2017). Perceived value and awareness levels of consumers towards EFTA products are important in terms of their contribution to sustainable agriculture, environment and, consequently, to economy.

Value of the product is considered as a major component of marketing (Chi, 2015). Perceived value by consumers is a general indication for the use of good or service they buy (Zeithaml, 1988; Chi and Kilduff, 2011). Major value forms perceived by consumers towards good or services are emotional value, social value, quality value and price value (Chi, 2015; Sweeney and Soutar, 2001).

Due to increasing population and consumption, chemical processes and wastes produced after the use of products of textile and apparel industry make a considerable contribution to environmental problems. Increasing the awareness of youth for these problems are legally the responsibilities of educationalists. Because of role academicians play for education of youth, investigation of their perceptions towards EFTA products is important. Academicians have been studied as an example in this study because they are professionals and social role models for younger generations. Aim of the present study was to determine empirically the factors affecting EFTA perception of academicians. 


\section{Theoretical Structure and Literature Review}

The differences in development between countries have been an issue for researchers and in decisions of policymakers since the beginning of 1900s. Although there are different indicators to measure development differences among countries, the most used is economic growth. Therefore, it is important how the countries with high economic growth achieve this and how the high growth rate will be sustained. With the developments in the world economy and the increasing competition among countries, the determinants of economic growth have also changed (Taş et al., 2017: 197). The starting point of economic growth theories is the study of Frank Ramsey named "A Mathematical Theory of Saving". With the changes $n$ the economy, many growth theories have been introduced over time. Ramsey's theory was followed by the Harrod-Domar model developed by Harrod and Domar. In the 1950s, new contributions were made to this area with the growth model developed by Solow (1956). Theories called Solow growth or Neo-classical growth models developed by Solow have suggested that growth will eventually follow a stagnant course, since the production function has a decreasing return to scale and technology is accepted as exogenous. Neo-classical growth model, which has an important role in explaining the growth process, had to be questioned due to its insufficiencies (Genç and Atasoy, 2010: 27 - 28). Much of the studies done investigating economic growth was devoted to Solow model (1956) until it was empirically tested in the late 1980s. Empirical findings did not support the foresight of Solow model that development disparities between countries will close over time despite of studies between 1950s and 1980s. that means poor countries could not converge rich countries. This has led to increased doubts about the assumption that technology is external which the most important assumption of the model is. Romer (1986) and Lucas (1988) assume technology as an endogenous variable, and this provided a more satisfying explanation for the reasons for the differences in the development rates of world economies. The technology and innovations created by the companies' $\mathrm{R} \& \mathrm{D}$ activities are at the core of their endogenous growth theory. Contrary to the Solow model, endogenous growth theories assume that countries can invest in technology, determine their technological levels and ensure their sustained economic growth. Therefore, it is no longer a requirement that the growth rates between countries will converge over time (Özer and Çiftçi, 2009: 219 - 220). By the 1980s, new growth theories, which have been at the center of the economic growth literature since the second half of the 1980s, have explained the technological development endogenously. Among the endogenous growth models, which consider the source of technological development as $\mathrm{R} \& \mathrm{D}$ activities, the first generation endogenous growth models imply that large-scale countries are growing at a higher rate depending on the number of researchers working in the $R \& D$ sector. Second generation endogenous growth models developed since the second half of the 1990s, predict that $\mathrm{R} \& \mathrm{D}$ expenditures will affect per capita income level rather than the long-term economic growth rate (Ünverdi, 2016: 39). In the core of new economic intelligence, science and technology exist. In this regard, companies have to make R\&D expenditures in order to continue gain competitiveness advantage and to continue make profitable business. Inventing a new information and technology or producing a new material, product and tools via existing information, creating and/or modifying a system, process and service including software production are all possible with making R\&D activities persistently. This group of activities carried out by companies constitutes the growth wheels of an economy when considered in a holistic sense. In order to compete with other economies, it is important to increase R\&D activities considerably. Knowledge economy is a kind of economy of speed and innovation. In the case of old economy, development efforts taking a long time period can be achieved in a few months. Recent developments in technology can change in a short time period and it can be old technology even in a month. Therefore, $R \& D$ activities in the information age are obligation rather than a need. Companies made $R \& D$ expenditures have the opportunity to produce technological innovation and to make their current technologies more comprehensive. Thanks to this opportunity, the relevant sector develops and increases the economic performance of the country (Ünal and Seçilmiş, 2013: 12 - 24). Developments in the technology through R\&D contribute to the economy in different ways. Technological development and the increasing competitiveness of firms and the increase in their profitability levels related to competitiveness are examples of micro contributions. On the other hand, due to technological advances, the acceleration of countries' economic growth and development processes can be cited as an example for macro effects. So the contribution may be in macroeconomic and macroeconomic levels. It is observed that especially the budgets devoted to $R \& D$ activities of developed countries make great contributions to the growth and development processes of these economies. The numbers of studies in the literature investigating causation linkage between variables are high and generally imply positive relation between variables (Yıldırım, 2017: 67). The literature investigating the relation between variables can be summarized as below. 
Oğuz (2019) investigates the relation between variables in G-8 countries. In the study, panel data method is applied to analyze 1997 - 2017 period. According to results obtained from empirical analysis, a 1 percent increase in R\&D expenditures leads to 0,36 percent increase in growth of related economies. Sarıdoğan (2019) examines possible relation between variables for 28 European Union countries. In the study, panel data method is applied to analyze 1995 - 2016 period. According to results obtained from empirical analysis, a 1 percent increase in $R \& D$ expenditures leads to 0,18 percent growth in European Union economies. Uçak et al. (2018) investigate the relation between variables in the case of Turkey. According to ARDL analysis results, R\&D expenditures affects economic growth positively and significant in the long run. $1 \%$ increase in R\&D increases growth 5,92\%. Sökmen and Açcı (2017) analyzes BRICS - T countries and investigate the relation between variables. Empirical analysis made by annual data belonging to $1999-2015$ period employs panel data analysis methods. Results imply that there is a long run relation between variables. Özcan and Ar1 (2014) investigate the relation between variables in fifteen OECD countries between years 1990 and 2011. Findings of panel data analysis imply that R\&D expenditures affect economic growth positively. Dereli and Salğar (2019) test the relation between variables in Turkey. According to results of Johansen co-integration method, a bi-directional causation linkage exists in the period of 1990 - 2015. Inal et al. (2017) tests the relation between variables in the case of the Turkish economy between years 1990 and 2013. Toda - Yamamoto Granger causality test results imply causation linkage and it runs from growth to R\&D unidirectionally. On the other hand, there is no effect of R\&D on economic growth. Ülger and Durgun (2017) investigate the relation between variables in France, Italy, Slovenia and Poland those are among OECD member countries. According to vector auto regressive analysis results for the period between years 1996 and 2015, a change in R\&D expenditures does not create any shock on GDP. But GDP is effective on R\&D expenditures. Yıldırım and Kantarcı (2018) analyze the relationship between variables by using annual data from 1998 to 2013 in terms of 15 emerging economies. According to the analysis result made using the panel data method, $R \& D$ expenditures do not have a statistically significant effect on economic growth. Dam and Yildı (2016) study the effect of R\&D expenditures on economic development in BRICS - TM economies in the period between years 2000 and 2012. Results imply that R\&D expenditures and innovation affect development positively and significantly. Gülmez and Yardımcioğlu (2012) examine the relationship between variables for 21 OECD countries. The time period covers 1990 - 2010 and employs panel data analysis. Empirical findings imply that $1 \%$ increase in R\&D expenditures increases economic growth by $0.77 \%$. According to the panel causality test results, it is determined that there is a bi-directional causation linkage between variables in the long run. Yaylalı et al. (2010) examine the relationship between variables between years 1990 and 2009 and employed ADF, co-integration and causality tests. According to the findings, causation linkage between variables is uni-directional and runs from $\mathrm{R} \& \mathrm{D}$ to growth.

\section{Empirical Findings}

In this study, relationship between gross domestic product per capita (GDPPC, hereafter) and ratio of research and development expenditures to gross domestic product ${ }^{\mathrm{a}}(\mathrm{R} \& \mathrm{D}$, hereafter) in the Brazilian, Russian, Indian, Chinese, South African and Turkish economies between years 2003 and 2017. The source of data employed is World Bank database. In order to prevent existence of heteroscedasticity problem, natural logarithm of GDPPC variable is used. Before unit root tests are employed, cross section dependency test is employed to determine possible relation between each country in the panel. In this test, absence of cross section dependency and existence of dependency is tested via null and alternative hypotheses, respectively.

\footnotetext{
${ }^{1}$ According to determination of World Bank, the ration of research and development expenditures to gross domestic product includes both capital and current expenditures in four main sectors. Commercial company, public, higher education and private non-profit organizations: R\&D basic researches, applied researches and experimental development.
} 
Table 1. Cross Section Dependency Tests Results

\begin{tabular}{lcccc}
\hline Model with Constant & \multicolumn{2}{c}{ GDPPC } & \multicolumn{2}{c}{ R\&D } \\
& Test Stat & Prob Value & Test Stat & Prob Value \\
\hline$C D_{l m}$ (BP, 1980) & 51.370 & $0.00^{* * *}$ & 22.036 & 0.107 \\
$C D_{l m}$ (Pesaran, 2004) & 7.558 & $0.00^{* * *}$ & 1.285 & $0.099^{*}$ \\
$C D \quad$ (Pesaran, 2004) & -2.697 & $0.037^{* *}$ & -2.185 & $0.014^{* *}$ \\
$L M_{a d j}$ (PUY, 2008) & -0.727 & 0.766 & 0.842 & 0.200 \\
\hline
\end{tabular}

Notes: In model $\Delta y_{i, t}=d_{i}+\delta_{i} y_{i, t-1}+\sum_{j=1}^{p_{i}} \lambda_{i, j} \Delta y_{i, t-j}+u_{i, t}$, lag length (pi) is accepted as one. ${ }^{* * *},{ }^{* *}$ and ${ }^{*}$ denote significance levels $1 \%, 5 \%$ and $10 \%$, respectively.

According to results, cross-section dependency exists between series. According to cross section dependency tests results, it is decided to employ second generation unit root tests those able to test whether variables are stationary for each country and to use even if time size is bigger than cross section size $(T>N)$, namely cross-sectional augmented Dickey-Fuller (CADF, hereafter). In CADF test, null hypothesis indicates the existence of unit root in series and vice versa for alternative one. When test statistic of CADF is smaller than critical value, series belonging to related country has no unit root and alternative hypothesis is accepted. When critical value is smaller than CADF test value, null hypothesis is accepted and series belonging to related country is not stationary.

Table 2. CADF Unit Root Test Results

\begin{tabular}{|c|c|c|c|c|}
\hline & \multicolumn{3}{|c|}{ Model with Constant } & Model with Constant and Trend \\
\hline & Lags & CADF-stat & Lags & CADF-stat \\
\hline \multicolumn{5}{|c|}{ GDPPC } \\
\hline Brazil & 1 & -0.260 & 1 & -1.751 \\
\hline Russia & 1 & -2.191 & 1 & -1.407 \\
\hline India & 2 & -1.042 & 2 & -1.072 \\
\hline China & 3 & $-7.029^{* * *}$ & 3 & 0.00 \\
\hline South Africa & 2 & -1.751 & 2 & -2.53 \\
\hline Turkey & 1 & -1.923 & 1 & -2.361 \\
\hline Panel & & $-2.366^{* *}$ & & -1.520 \\
\hline \multicolumn{5}{|l|}{$\underline{R \sigma D}$} \\
\hline Brazil & 1 & -2.429 & 2 & $-8.942^{* * *}$ \\
\hline Russia & 1 & -1.717 & 1 & -3.047 \\
\hline India & 1 & -1.880 & 1 & -2.759 \\
\hline China & 2 & -2.122 & 1 & -0.864 \\
\hline South Africa & 1 & -1.068 & 2 & 0.592 \\
\hline Turkey & 1 & -2.545 & 1 & -3.061 \\
\hline Panel & & -1.960 & & $-3.014^{* *}$ \\
\hline
\end{tabular}

Notes: Maximum lag length is accepted as four and optimal lag lengths are determined according to Schwarz information criterion. For CADF critical values please see Pesaran (2007). Panel statistic is average of CADF statistics.

When we evaluate test statistics and critical values obtained by Peseran (2007), R\&D variable of Brazil is stationary in significance level $1 \%$ for model with constant and trend. Also gross domestic product per capita variable of China is stationary in significance level $1 \%$ for model with constant. The main difference between bootstrap and other panel unit root tests is critical values are obtained via bootstrap process in bootstrap panel unit root test. Smith et al. (2004) "bootstrap" panel unit root test can be applied if there is panel unit root test cross section dependency. In Smith et al. (2004) "bootstrap" panel unit root test, hypotheses are; 
H0: Series contain unit root and it is not stationary.

H1: Series do not contain unit root and it is stationary.

Table 3. Smith et al. (2004) "bootstrap” Panel Unit Root Test Results

\begin{tabular}{|c|c|c|c|c|}
\hline \multirow[b]{3}{*}{ Levels } & \multicolumn{2}{|c|}{ Model with constant } & \multicolumn{2}{|c|}{ Model with Constant and Trend } \\
\hline & & Bootstrap & & Bootstrap \\
\hline & Test Stat & Prob. Value & Test Stat & Prob. Value \\
\hline$\underline{G D P P C}$ & -2.737 & $0.00^{* * *}$ & -0.951 & 0.964 \\
\hline$\underline{R \sigma D}$ & -2.199 & $0.058^{*}$ & -2.436 & 0.170 \\
\hline \multicolumn{5}{|c|}{ First difference } \\
\hline GDPPC & -2.282 & $0.042^{* *}$ & -2.935 & $0.048^{* *}$ \\
\hline$\underline{R \sigma D}$ & -2.399 & $0.011^{* *}$ & -2.416 & $0.011^{* *}$ \\
\hline
\end{tabular}

Notes: Maximum lag length is accepted as four and optimal lag length is determined with the general to specific approach. Probability values are obtained after 5000 bootstrap simulation. ${ }^{* * *}{ }^{* *}$ and ${ }^{*}$ denote statistically significance levels of coefficients in $1 \%, 5 \%$ and $10 \%$ significance levels, respectively.

Gross domestic product per capita is stationary in $1 \%$ significance level and ration of research and development expenditures to gross domestic product is stationary in $5 \%$ significance level in level. These results are valid for model with constant. On the other hand, variables contain unit root in level for model with constant and trend. Both gross domestic product per capita and ration of research and development expenditures to gross domestic product variables do not contain and unit root when we differentiate them. So, first differences of both variables are stationary in significance level $5 \%$.

Table 4. Cross Section Dependency and Homogeneity Test Results

\begin{tabular}{lcc}
\hline Regression Model: & & \\
$G D P_{i t}=\alpha_{i}+\beta_{1 i} e c_{i t}+\varepsilon_{i t}$ & Test Stat & Prob Value \\
\hline Cross-section dependency tests: & & \\
\hline$L M \quad(B P, 1980)$ & 75.854 & $0.00^{* * *}$ \\
$C D_{l m}$ (Pesaran, 2004) & 11.110 & $0.00^{* * *}$ \\
$C D \quad$ (Pesaran, 2004) & 8.224 & $0.00^{* * *}$ \\
$L M_{a d j}($ PUY, 2008) & 11.845 & $0.00^{* * *}$ \\
$\underline{\text { Homogeneity tests: }}$ & & \\
$\tilde{\Delta}$ & 5.379 & $0.00^{* * *}$ \\
$\tilde{\Delta}_{a d j}$ & 5.968 & $0.00^{* * *}$ \\
Note: ${ }^{* * *},{ }^{* *}$ and ${ }^{*}$ denote statistically significance levels $1 \%, 5 \%$ and $10 \%$, respectively.
\end{tabular}

In table 4, probability values belonging to each test imply alternative hypothesis claiming invalidity of cross section dependency and homogeneity in $1 \%$ significance level. For this reason, it is needed to take cross section dependency into account and to continue to analysis by employing heterogeneous co-integration methods. 
Table 5. Results of Co-integration Tests Taking Cross Section Dependency

\begin{tabular}{|c|c|c|c|c|c|c|}
\hline & \multicolumn{3}{|c|}{ Model with Constant } & \multicolumn{3}{|c|}{ Model ve Constant and Trend } \\
\hline & Test Stat & $\begin{array}{c}\text { Asymptotic Prob. } \\
\text { Value }\end{array}$ & $\begin{array}{l}\text { Bootstrap } \\
\text { Prob. } \\
\text { Value }\end{array}$ & Test Stat & $\begin{array}{c}\text { Asymptotic Prob. } \\
\text { Value }\end{array}$ & $\begin{array}{c}\text { Bootstrap } \\
\text { Prob. } \\
\text { Value }\end{array}$ \\
\hline$L M_{N}^{+}$ & 14.82 & $0.00^{* * *}$ & $0.00^{* * *}$ & 6.191 & $0.024^{* *}$ & $0.00^{* * *}$ \\
\hline
\end{tabular}

Notes: Bootstrap probability values are obtained after 1.000 repetitive simulations. Asymptotic probability values are obtained from normal distribution. ${ }^{* * *},{ }^{* *}$ and ${ }^{*}$ denote that alternative hypotheses are accepted in significance levels $1 \%(0.01), 5 \%(0.05)$ and $10 \%(0.1)$, respectively.

The null hypothesis of LM test claims that there is no long run relation between variables, alternative hypothesis of the test claims existence of long run relation between variables. In model with constant and trend, asymptotic probability value in $5 \%$ significance level and probability values belonging to other models in $1 \%$ significance level give information about the acceptance of alternative hypothesis claiming existence of co-integration relationship between variables.

Table 6. Panel VAR and VECM Causality Test Results

\begin{tabular}{cccc}
\hline & \multicolumn{2}{c}{ Short Run Causality } & Long Run Causality \\
\hline & $\Delta(\mathrm{GDPPC})$ & $\Delta(\mathrm{R} \& \mathrm{D})$ & ECT(-1) \\
\hline$\Delta(\mathrm{GDPPC})$ & - & $5.974(0.014)^{* *}$ & $-0.131194[-2.05288]^{* *}$ \\
$\Delta(\mathrm{R} \& \mathrm{D})$ & $1.157(0.282)$ & - & $-2.09 \mathrm{E}-05[-0.00031]$
\end{tabular}

Notes: () shows probability value, [] shows t statistics. ${ }^{* * *},{ }^{* *}$ and ${ }^{*}$ denote acceptance of alternative hypothesis in $1 \%(0.01), 5 \%(0.05)$ and $10 \%$ (0.1) significance levels, respectively.

According to results presented in table 6 , there is no causation linkage running from R\&D to GDPPC in the short run. On the other hand, uni-directional causality running from GDPPC to R\&D exists in the short run. In the long run, direction of causality reverses. Uni-directional causality running from R\&D to GDPPC exists in the long run. On the other hand, uni-directional causality running from GDPPC to R\&D disappears in the long run.

The R\&D activities may be expensive and taking beneficial results such as invention of useful product can take long time. Obtaining useful product would increase added value and so, gross domestic product will increase. In this regard, it is not possible to obtain effect of R\&D on GDPPC. This is consistent with findings. On the other hand, developing economies can allocate resources to $R \& D$ activities. How the economy develops more source goes to $R \& D$ in different institutions such as private sector, universities and research centers of government. In the light of empirical findings, results indicating unidirectional causality running from GDPPC to R\&D is consistent with theoretical explanations.

Results of long run causality analysis are also in line with theoretical background. Expenditures focused on R\&D activities in a longer time periods increases probability of inventing useful products by private sector and/or public. This would increase gross domestic product via increasing production. So, in the long run, uni-directional causality running from $\mathrm{R} \& \mathrm{D}$ to GDPPC would appear. This is consistent with empirical findings.

Table 7. Emirmahmutoğlu and Köse Panel Causality Test Results

\begin{tabular}{lccccc}
\hline Country & $\begin{array}{c}\text { La } \\
\mathrm{g}\end{array}$ & \multicolumn{2}{c}{ GDPPC=>R\&D } & \multicolumn{2}{c}{$\mathrm{R} \& D=>$ GDPPC } \\
& & Wald & Prob Value & Wald & Prob Value \\
\hline Brazil & 1 & 0.217 & 0.641 & 1.432 & 0.231 \\
Russia & 1 & 0.204 & 0.651 & 1.632 & 0.201 \\
India & 1 & 0.594 & 0.440 & 0.083 & 0.773
\end{tabular}




\begin{tabular}{lccccc} 
China & 1 & 0.065 & 0.798 & 0.786 & 0.375 \\
South Africa & 2 & 1.569 & 0.456 & 3.414 & 0.181 \\
Turkey & 3 & 13.491 & $0.00^{* * *}$ & 11.143 & $0.010^{* *}$ \\
\hline \multicolumn{1}{c}{ Fisher } & $\begin{array}{c}\mathbf{1 6 . 6 1} \\
\mathbf{2}\end{array}$ & $\mathbf{0 . 1 6 4}$ & $\begin{array}{c}\mathbf{2 1 . 0 4} \\
\mathbf{6}\end{array}$ & $\mathbf{0 . 0 4 9 * *}$ \\
& & & &
\end{tabular}

Note: ${ }^{* * *},{ }^{* *}$ and ${ }^{*}$ denote $1 \%, 5 \%$ and $10 \%$ significance levels, respectively.

Emirmahmutoğlu and Köse test results are presented above. No causation linkage from GDPPC to R\&D or R\&D to GDPPC in countries examined, except the Turkish economy. In Turkey case, uni-directional causality running from GDPPC to R\&D is valid in $1 \%$ significance level and uni-directional causality running from R\&D to GDPPC is valid in $5 \%$ significance level. According to Fisher statistics, there is a uni-directional causality running from R\&D to GDPPC in significance level $5 \%$ as a whole country group.

The country specific results show that only in Turkey there is a bi-directional causality between R\&D and GDPPC. This result may stem from stabilization program has begun to implement in 2002, just after the economic crisis in the Turkish economy. Economic program implemented has given priority high - tech production and subventions. That is why causation linkage may exist.

\section{Conclusion and Policy Implications}

Although there are many determinants affecting the economic growth, which is the main purpose of the economic activities carried out by the countries, the rapidly developing technology and the innovations it provides have an increasing effect on growth. The developments in the field of technology and innovation contribute to the growth and prosperity increase by increasing efficiency with technology intensive production in the economy. The R\&D concept comes to the fore in ensuring or transferring these developments. When the economies of developed countries are analyzed, it is seen that they have a high technology share in R\&D oriented investments and expenditures.

In the study, R\&D expenditure and economic growth relation is investigated in T-BRICS countries via panel data econometric methods in 2003 - 2017 period. Different from existing studies, this study employs co-integration and unit root test methods investigating cross section dependency and panel data analysis allowing obtaining country specific results.

The results show that there is a uni-directional causality running from economic growth to $R \& D$ expenditures in the short run and uni-directional causality running from R\&D expenditures in the long run. Moreover, country specific results imply bi-directional causality in the Turkish economy.

Results for BRICS - T countries are partly consistent with existing literature about BRICS - T countries. Results about long run relation support Sökmen and Açcı (2017) and partly Dam and Yıldız (2016).

When we interpret the results, it is possible to conclude that $\mathrm{R} \& \mathrm{D}$ activities may be expensive and taking beneficial results such as invention of useful product can take long time. Obtaining useful product would increase added value and so, gross domestic product will increase. In this regard, it is not possible to obtain effect of R\&D on economic growth. This is consistent with findings. On the other hand, developing economies can allocate resources to $R \& D$ activities. How the economy develops more source goes to $R \& D$ in different institutions such as private sector, universities and research centers of government. In the light of empirical findings, results indicating uni-directional causality running from economic growth to $\mathrm{R} \& \mathrm{D}$ is consistent with theoretical explanations.

Results of long run causality analysis are also in line with theoretical background. Expenditures focused on R\&D activities in a longer time periods increases probability of inventing useful products by private sector and/or public. This would increase gross domestic product via increasing production. So, in the long run, uni-directional causality running from $\mathrm{R} \& \mathrm{D}$ to economic growth would appear. This is consistent with empirical findings. 
In the Turkish economy case, it is possible to conclude that the stabilization programs encouraging $\mathrm{R} \& \mathrm{D}$ activities and give some stimulation in early 2000s. In this regard, it is important to implement fiscal policies encouraging R\&D expenditures made by private sector. By doing so, innovative product inventions may increase in the medium and long run.

\section{References}

Breusch, T., Pagan, A., (1980). The Lagrange Multiplier Test and Its Application to Model Specification in Econometrics. Rev. Econ. Stud. 47, 239-253.

Dam, M. M., \& Yıldız, B. (2016). BRICS-TM Ülkelerinde Ar-Ge ve İnovasyonun Ekonomik Büyüme Üzerine Etkisi: Ekonometrik Bir Analiz. Akdeniz Üniversitesi İktisadi ve İdari Bilimler Fakültesi Dergisi, 16(33), 220-236.

Dereli, D. D., \& Salğar, U. (2019). AR-GE Harcamaları İle Büyüme Arasındaki İlişki: Türkiye Üzerine Bir Değerlendirme. Journal of Life Economics, 6(3), 345-360.

Emirmahmutoglu, F. ve Kose, N. (2011). Heterojen Karışık Panellerde Granger Nedenselliğinin Test Edilmesi. Ekonomik Modelleme, 28 (3), 870-876.

Genç, A. G. M. C., \& Atasoy, A. G. Y. (2010). Ar\&Ge Harcamaları ve Ekonomik Büyüme İlişkisi: Panel Veri Analizi. Bilgi Ekonomisi ve Yönetimi Dergisi, 5(2), 27-34.

Gülmez, A., \& Yardımcıoğlu, F. (2012). OECD Ülkelerinde Ar-Ge Harcamaları ve Ekonomik Büyüme İlişkisi: Panel Eşbütünleşme ve Panel Nedensellik Analizi (1990-2010). Maliye Dergisi, 163(1), 335-353.

Oguz, S. (2019). Ar-Ge Harcamalarının Ekonomik Büyüme Üzerindeki Etkisi: G8 Ülkeleri İçin Bir Panel Veri Analizi. Business and Organization Research, 252-253.

Özcan, B., \& Arı, A. (2014). Araştırma-Geliştirme Harcamaları ve Ekonomik Büyüme İlişkisi: Panel Veri Analizi. Maliye Dergisi, 166(1), 39-55.

Özer, M., \& Çiftçi, N. (2009). Ar-Ge Tabanlı İçsel Büyüme Modelleri ve Ar-Ge Harcamalarının Ekonomik Büyüme Üzerine Etkisi: OECD Ülkeleri Panel Veri Analizi. Sosyal Ekonomik Araştırmalar Dergisi (2009), 219-240.

Pesaran, Hasem, M., (2004), "General Diagnostic Tests for Cross Section Dependence in Panels", Working Paper No:0435, University of Cambridge.

Pesaran, M. H. (2007). A Simple Panel Unit Root Test in The Presence of Cross-Section Dependence. Journal of Applied Econometrics, 22(2), 265-312.

Pesaran, M.H., Ullah, A., Yamagata, T., (2008). A Bias-Adjusted LM Test of Error Cross Section Independence. Econometrics Journal 11, 105-127.

Sarıdoğan, H. Ö. (2019). Araştırma Geliştirme Harcamalarının Ekonomik Büyüme Üzerindeki Etkileri Üzerine Bir İnceleme: AB28 Örneği. Yönetim ve Ekonomi Araşttrmaları Dergisi, 17(4), 17-34.

Smith, L. V., Leybourne, S., Kim, T. H., \& Newbold, P. (2004). More Powerful Panel Data Unit Root Tests With an Application to Mean Reversion in Real Exchange Rates. Journal of Applied Econometrics, 19(2), 147-170.

Sökmen, F. Ş., \& Yunus, A. Ç. C. I. (2017). BRICS-T Ülkelerinde Ar-Ge Harcamalarının Ekonomik Büyümeye Etkisi. Kahramanmaraş Sütçü İmam Üniversitesi İktisadi ve İdari Bilimler Fakültesi Dergisi, 7(2), 83-100.

Sungur, O., Aydın, H. İ., \& Eren, M. V. (2016). Türkiye'de Ar-Ge, İnovasyon, İhracat ve Ekonomik Büyüme Arasındaki İlişki: Asimetrik Nedensellik Analizi. Suleyman Demirel University Journal of Faculty of Economics \& Administrative Sciences, 21(1).

Şebnem, T. A. Ş., Taşar, İ., \& Yunus, A. Ç. C. I. (2017). Ar-Ge Harcamaları ve Ekonomik Büyüme Arasındaki İlişki: Türkiye Örneği. Ömer Halisdemir Üniversitesi İktisadi ve İdari Bilimler Fakültesi Dergisi, 10(2), 178-187. 
Uçak, S., Kuvat, Ö., \& Aytekin, A. G. (2018). Türkiye'de Arge Harcamaları-Büyüme İlişkisi: ARDL Yöntemi. Celal Bayar University Journal of Social Sciences/Celal Bayar Üniversitesi Sosyal Bilimler Dergisi, 16(2), 129-160.

Ülger, Ö., \& Durgun, Ö. (2017). Seçilmiş OECD Ülkelerinde AR-GE Harcamalarının Büyüme Üzerine Etkileri. Ömer Halisdemir Üniversitesi İktisadi ve İdari Bilimler Fakültesi Dergisi, 10(4), 105-130.

Ünal, T., \& Seçilmiş, N. (2013). Ar-Ge Göstergeleri Açısından Türkiye ve Gelişmiş Ülkelerle Kıyaslaması. İşletme ve İktisat Çalı̧̧maları Dergisi, 1(1), 12-25.

Ünverdi, B. (2016). Ar-Ge Harcamalarının Ekonomik Büyümeye Etkisi: Bir Literatür İncelemesi. Hacettepe Üniversitesi Sosyal Bilimler Enstitüsü, Yüksek Lisans Tezi, Ankara.

Veysel, İ. N. A. L., Altıntaş, N., \& Çalışkan, M. (2017). Ar-Ge Harcamalarının Ekonomik Büyümeye Etkisi: Türkiye Özelinde Nedensellik Analizi. Sakarya İktisat Dergisi, 5(1), 34-47.

Yaylalı, M., Yusuf, A. K. A. N., \& Cem, I. Ş. I. K. (2010). Türkiye'de Ar\&Ge Yatırım Harcamaları ve Ekonomik Büyüme Arasındaki Eş-Bütünleşme ve Nedensellik İlişkisi: 1990-2009. Bilgi Ekonomisi ve Yönetimi Dergisi, 5(2), 13-26.

Yıldırım, D. Ç., \& Kantarcı, T. (2018). Araştırma Geliştirme Harcamaları ve Ekonomik Büyüme İlişkisi Üzerine Bir Panel Veri Analizi. Anemon Muş Alparslan Üniversitesi Sosyal Bilimler Dergisi, 6(5), 661-670.

Yıldırım, F. Türkiye'deki Ar-Ge Harcamalarının Ekonomik Büyümeye Etkisi. I. Uluslararası Ekonomi, Finans ve Ekonometri Öğrenci Sempozyumu (EFEOS), Tam Metin Bildiri Kitabı, 67. 